\title{
Biodegradable polylactide/hydroxyapatite nanocomposite foam scaffolds for bone tissue engineering applications
}

\author{
Claire Delabarde $\cdot$ Christopher J. G. Plummer • \\ Pierre-Etienne Bourban · Jan-Anders E. Månson
}

Received: 25 March 2011/Accepted: 8 March 2012/Published online: 22 March 2012

(C) Springer Science+Business Media, LLC 2012

\begin{abstract}
Supercritical carbon dioxide processing of poly-L-lactide (PLLA)/hydroxyapatite (nHA) nanocomposites was investigated as a means to prepare foams suitable as scaffolds in bone tissue engineering applications. For given foaming parameters, addition of nHA to the PLLA gave reduced cell sizes and improved homogeneity in the size distribution, but did not significantly affect the degree of crystallinity, which remained of the order of $50 \mathrm{wt} \%$ in all the foams. The compressive modulus and strength were primarily influenced by the porosity and there was no significant reinforcement of the matrix by the nHA. The mechanical properties of the foams were nevertheless comparable with those of trabecular bone, and by adjusting the saturation pressure and depressurization rate it was possible to generate porosities of about $85 \%$, an interconnected morphology and cell diameters in the range 200-400 $\mu \mathrm{m}$ from PLLA containing 4.17 vol\% nHA, satisfying established geometrical requirements for bone replacement scaffolds.
\end{abstract}

\section{Introduction}

About $10^{6}$ fractures are reported annually in the USA alone, of which 500,000 (typically hips, ankles or tibia) require bone grafts [1], and the bone graft and bone substitute market was worth about $\$ 1.5$ billion in 2000 [2]. Autografts are attractive in terms of osteoconductivity

C. Delabarde · C. J. G. Plummer ( $₫)$ · P.-E. Bourban ·

J.-A. E. Månson

Laboratoire de Technologie Des Composites Et Polymères

(LTC), Station 12, École Polytechnique Fédérale de Lausanne

(EPFL), 1015 Lausanne, Switzerland

e-mail: christopher.plummer@epfl.ch (provision of a suitable environment for bone forming cells (osteblasts) [3]), and lead to lower rejection rates and pathogen transmission than allo- or xenografts. Use of autografts is nevertheless declining owing to limited availability, pain/complications, long operating times and blood loss during surgery to extract the graft. The bone graft substitute market has hence undergone rapid expansion, but there remains an urgent demand for improved synthetic bioresorbable materials with appropriate morphologies (interconnected porosity in the range 50-90\%, pore diameters of 200-400 $\mu \mathrm{m}[4,5])$ and degradation rates $[6,7]$, and mechanical properties close to those of natural bone.

Poly-L-lactide (PLLA) is a semicrystalline thermoplastic widely used in biomedical applications owing to its biocompatibility and biodegradability [6, 8-14]. It is currently under consideration for use in porous biodegradable scaffolds for bone repair, but to improve osteoconductivity it is of interest to modify such constructs with bioactive ceramics ("bioceramic") such as hydroxyapatite (HA) [15, 16]. A recent trend is to exploit the improved properties of polymer/bioceramic nanocomposites. Here, the modifier particles are comparable in size to those in natural bone, which consists of around $60 \mathrm{wt} \%$ ceramic inclusions, similar to HA in composition and structure, embedded in a polymer (collagen) matrix [17-19]. Nanocrystalline HA (nHA), for example, shows enhanced osteoblast adhesion, and surface deposition of calcium-containing materials, and enhanced osteoconduction when introduced into a polymer matrix [1, 20, 21].

Efforts have been made to produce porous polymer/ bioceramic constructs by solvent casting/particulate leaching, thermally induced phase separation or emulsion freeze drying [22-24]. However, these approaches typically involve organic solvents, which is a problem for 
implementation [25], providing a strong driving force for the development of solvent-free processing techniques [11-14, 26], such as supercritical fluid foaming [27, 28]. In supercritical fluid foaming, pressure and temperature control is determinant for the growth and stabilization of a cellular morphology and hence the final properties of the material, which may also vary with filler content, crystallinity, and fluid content [27, 29]. Filler addition generally induces heterogeneous cell nucleation owing to a local reduction in the free energy of nucleation, and hence a decrease in average cell size and an increase in cell density, as in polylactide/silk fibroin foams [30], polylactide/layered silicate nanocomposite foams [31, 32], and other types of polymer/layered silicate foams [33-36]. It may also influence the tensile modulus and fracture toughness [37, 38], and the morphology of semicrystalline polymers such as PLLA. Increases in the spherulite nucleation density have already been reported in PLLA in the presence of layered silicates [35] and nHA [39], coupled with decreased spherulite growth rates, which may be accounted for by strong increases in melt viscosity. However, to the authors' knowledge, the effect of well dispersed nHA on PLLA foams obtained by supercritical fluid foaming has yet to be described in detail in the open literature. In what follows we present an investigation of the feasibility of producing PLLA/nHA foams with a suitable morphology for bone replacement using a new custom-built autoclave for supercritical $\mathrm{CO}_{2}$ foaming. The goal was to investigate the effects of foaming parameters and nHA content on the morphology, density, cell size, crystallinity and mechanical behavior, so as to identify appropriate conditions for the preparation of foams suitable for clinical testing as bone replacement scaffolds.

\section{Experimental}

Bioresorbable PLLA, intrinsic viscosity $1.6 \mathrm{dL} / \mathrm{g}$ (Boehringer Ingelheim, Germany), was provided as flakes and dried overnight at $75^{\circ} \mathrm{C}$ under vacuum prior to use. Studies of PLLA with comparable intrinsic viscosity by gel permeation chromatography indicate a polydispersity of 1.5 and a weight average molar mass, $M_{w}$, of about $150,000 \mathrm{~g} /$ mol, which decreases by approximately $10 \%$ after processing under conditions equivalent to those described below [40]. Hydroxyapatite nanopowder (nHA, nominal mean diameter $<200 \mathrm{~nm}$ from BET analysis, Sigma-Aldrich) was used without further purification or treatment.

Prior to foaming, a homogeneous mixing of nanoparticles and PLLA was achieved by melt-extrusion. PLLA and nHA were compounded under dry nitrogen using a miniextruder equipped with twin conical co-rotating screws and a capacity of $5 \mathrm{~cm}^{3}$ (DSM Micro 5 compounder, Netherlands). A screw rotation rate of $110 \mathrm{rpm}$, a temperature of $200{ }^{\circ} \mathrm{C}$ and a residence time of 4 min were used to prepare PLLA compounds containing 0,2 and 4.17 vol\% of nHA in granulate form, which were subsequently stored at $-18^{\circ} \mathrm{C}$ (at higher nHA contents, it became difficult to introduce the dry mix into the extruder). These conditions led to uniform dispersions of the nHA particles in the PLLA matrix as demonstrated elsewhere [39] (90 vol\% of the particles had a diameter less than $980 \mathrm{~nm}$ and $50 \mathrm{vol} \%$ had a diameter less than $360 \mathrm{~nm}$ ). Approximately $5 \mathrm{~g}$ of the compounded PLLA/nHA granulate was then loaded into an open cylindrical mold (25 $\mathrm{mm}$ in diameter and $35 \mathrm{~mm}$ in height) and foamed using a high-pressure, high-temperature autoclave (SITEC-Sieber Engineering, Switzerland).

In initial tests, the same nominal process parameters (saturation pressure $\left(P_{\text {sat }}\right) 200$ bar, and saturation temperature $\left(T_{\text {sat }}\right) 200{ }^{\circ} \mathrm{C}$ ) were used as in studies with an earlier autoclave [11]. However, the new autoclave incorporated a range of improvements with regard to the control of foam morphologies and properties, including systems to limit temperature gradients in the chamber, which can lead to uncontrolled microstructural gradients, and more precise pressure and temperature control. It was therefore necessary to adjust the process parameters in the present case, a nominal $T_{\text {sat }}$ of $200{ }^{\circ} \mathrm{C}$, for example, leading to too low a melt viscosity, excessive collapse of the pores and highly inhomogeneous microstructures. $T_{\text {sat }}$ was therefore decreased to $175^{\circ} \mathrm{C}$ and $165^{\circ} \mathrm{C}$ and $P_{\text {sat }}$ was varied between 100 and 250 bars. Although these $T_{\text {sat }}$ are below the nominal melting point of the as-received PLLA (about $180{ }^{\circ} \mathrm{C}$ ), they remain well above the melting point of PLLA in the presence of $\mathrm{CO}_{2}$ at comparable pressures (about $\left.130{ }^{\circ} \mathrm{C}[41,42]\right) . T_{\text {sat }}$ and $P_{\text {sat }}$ were maintained for 10 min to allow adequate diffusion of the supercritical $\mathrm{CO}_{2}$ into the molten PLLA. Foam expansion was then achieved by pressure release, controlled by a back-pressure regulator, with additional oil cooling. Representative temperature and pressure processing curves are shown in Fig. 1 and the range of processing parameters investigated are given in Table 1. The depressurization rates, $d P / d t$, and the associated cooling rates, $d T / d t$ (which could not be controlled independently with the present set-up), were calculated from the slope of $P(t)$ in the range 200-250 to 50 bars and of $T(t)$ in the ranges $175-165^{\circ} \mathrm{C}$ to $100{ }^{\circ} \mathrm{C}$ and $100-75^{\circ} \mathrm{C}$. At lower $P$, the depressurization rate dropped to $0.2-0.6 \mathrm{bar} / \mathrm{s}$ for all the foams, regardless of the conditions.

The morphology of the foams was observed by scanning electron microscopy (SEM, Philips XL30) at a tension of $3 \mathrm{kV}$ in secondary electron mode. Sections were taken perpendicular to the foaming direction (see Fig. 2) and coated with carbon. The dispersion of the nHA in the foam walls and at the foam wall surfaces was also investigated by transmission electron microscopy (TEM, Philips CM12) at $100 \mathrm{kV}$. The foams were embedded in an epoxy resin. 

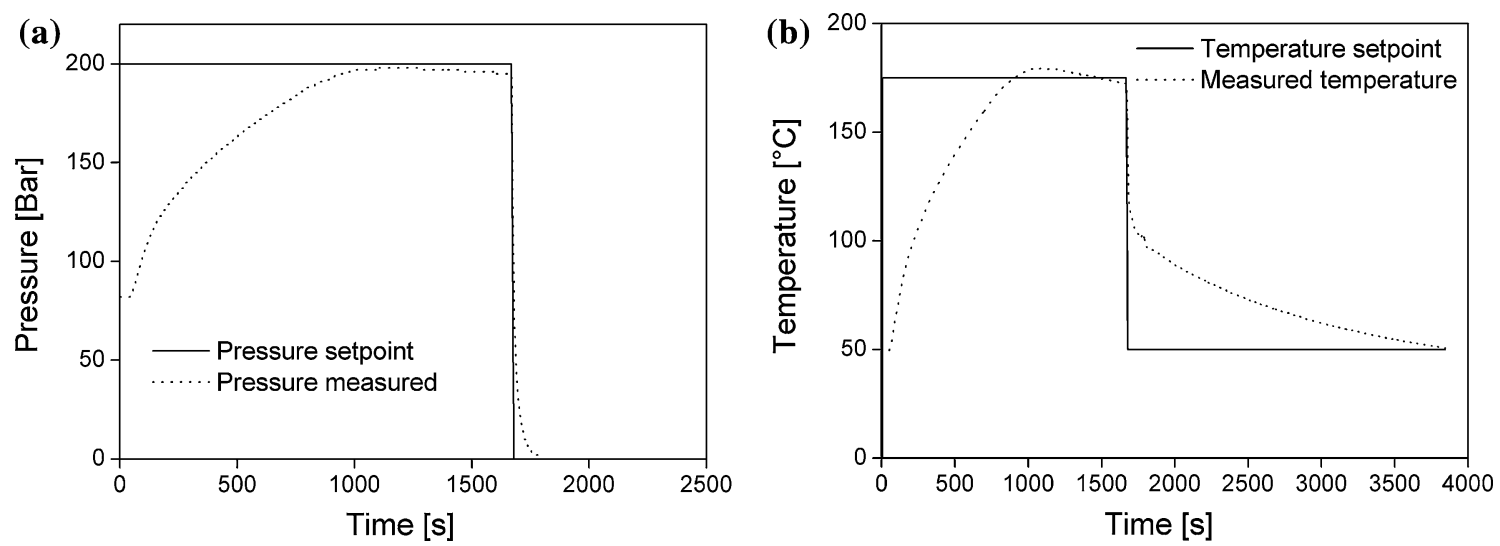

Fig. 1 Representative a pressure and $\mathbf{b}$ temperature profiles during $\mathrm{CO}_{2}$ supercritical foam processing (in this case for foam $\mathrm{B}$ )

Table 1 Foaming parameters

\begin{tabular}{llllll}
\hline $\begin{array}{l}\text { Specimen } \\
\text { designation }\end{array}$ & $\begin{array}{l}\text { Saturation } \\
\text { temperature }\left({ }^{\circ} \mathrm{C}\right)\end{array}$ & $\begin{array}{l}\text { Saturation } \\
\text { pressure }(\mathrm{Bar})\end{array}$ & $\begin{array}{l}\text { Depressurization } \\
\text { rate }(\mathrm{Bar} / \mathrm{s})\end{array}$ & $\begin{array}{l}\text { Cooling rate from } \\
T_{\text {sat }} \text { to } 110{ }^{\circ} \mathrm{C}(\mathrm{K} / \mathrm{s})\end{array}$ & $\begin{array}{l}\text { Cooling rate from } \\
110 \text { to } 75{ }^{\circ} \mathrm{C}(\mathrm{K} / \mathrm{s})\end{array}$ \\
\hline $\mathrm{A}$ & 175 & 100 & 4.8 & 1.2 & 0.04 \\
$\mathrm{~B}$ & 175 & 200 & 10.6 & 2.5 & 0.05 \\
$\mathrm{C}$ & 175 & 200 & 16.5 & 4.5 & 0.04 \\
$\mathrm{D}$ & 175 & 200 & 21.1 & 5.6 & 0.035 \\
$\mathrm{E}$ & 165 & 200 & 2.6 & 1.16 & 0.03 \\
$\mathrm{~F}$ & 165 & 200 & 5.8 & 2.2 & 0.03 \\
$\mathrm{G}$ & 165 & 200 & 12.2 & 3.8 & 0.02 \\
$\mathrm{H}$ & 165 & 250 & 5.8 & 2 & 0.03 \\
$\mathrm{I}$ & 165 & 250 & 11.6 & 3.8 & 0.05 \\
\hline
\end{tabular}

$80 \mathrm{~nm}$ thick sections were then prepared from the resulting blocks using an ultramicrotome (Reichert-Jung Ultracut-E) at ambient temperature with a $35^{\circ}$ diamond knife (Diatome) and mounted on formvar/carbon covered copper TEM grids.

$\mathrm{X}$-ray micro-computed tomography $(\mu \mathrm{CT})$ was also used for systematic morphological characterization of selected foams [12, 43-46]. The measurements were performed using a Skyscan 1076 micro-CT scanner (Skyscan). Five cylindrical specimens $(3 \mathrm{~mm}$ in diameter and $3 \mathrm{~mm}$ in height) were cut from the foams and scanned at $42 \mathrm{kV}$, with an intensity of $242 \mu \mathrm{A}$, an exposure time of $800 \mathrm{~ms}$, and a spatial resolution of $9 \mu \mathrm{m}$, without a filter. The reconstruction and analysis were carried out using Geomagic, NRecon and CTan software (Skyscan). A second order polynomial correction was used to reduce beamhardening effects.

The foam densities were measured by weighing cylinders with a height of $8 \mathrm{~mm}$ and a diameter of $8 \mathrm{~mm}$ cut from the foams (Fig. 2). The porosity $\left(\varepsilon^{*}\right)$ was evaluated from
Fig. 2 a Schematic

representation showing foaming direction in the mold (indicated by the arrow) and the geometry of the cylindrical specimens used for density measurements and compressions tests, b images of the as-molded foam (left) and the cylindrical specimens (right) (a)

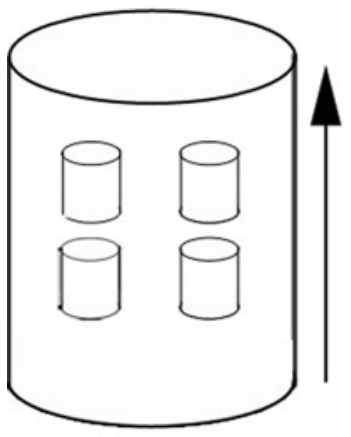

(b)

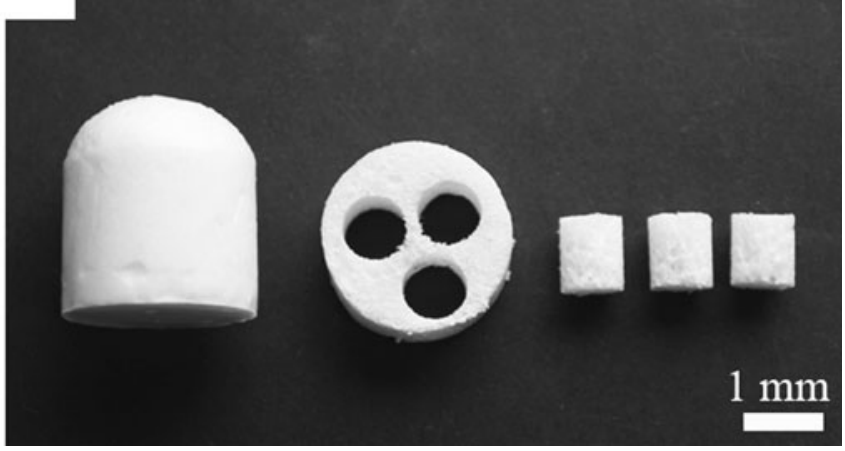


$\rho_{s}=V_{f} \rho_{f}+V_{p} \rho_{p}$

$\varepsilon^{*}=1-\frac{\rho}{\rho_{s}}$

where $\rho_{s}$ is the density of the bulk composite, $\rho_{f}$ and $\rho_{p}$ are the densities, and $V_{f}$ and $V_{p}$ are the volume fractions of the nHA and PLLA respectively. At least five specimens were characterized for each set of foaming conditions.

The influence of the nHA on the dynamic rheological properties was studied using an Advanced Rheometric Expansion System (ARES) (Rheometrics Europe GmbH). The measurements were performed in dynamic oscillatory shear mode using 25 diameter parallel plates. Frequency sweeps from 0.1 to $100 \mathrm{rad} / \mathrm{s}$ were carried out on $1 \mathrm{~mm}$ thick, $25 \mathrm{~mm}$ diameter compression molded discs at $10 \%$ strain, which is in the linear viscoelastic range. The measurements were performed in triplicate to check for reproducibility.

Thermal properties were determined by differential scanning calorimetry (DSC, TA Instruments Q100). Specimens of approximately $3 \mathrm{mg}$ were cut from the foams and placed in aluminum pan. They were held at $30^{\circ} \mathrm{C}$ for $1 \mathrm{~min}$ and then heated at $10 \mathrm{~K} / \mathrm{min}$ to $210^{\circ} \mathrm{C}$. The degree of crystallinity of the matrix, $X_{c}$, was determined in each case from

$X_{c}=\frac{\Delta H}{\Delta H_{f}^{0}\left(1-W_{n H A}\right)}$.

where $\Delta H$ was estimated from the total enthalpy change in heating scans with respect to an interpolated baseline between $T_{g}$ and a temperature of about $20 \mathrm{~K}$ above the final melting point $T_{m}$, and $\Delta H_{f}^{0}$ is the melting enthalpy per unit mass of an infinitely large crystal of the $\alpha$ phase of PLLA, taken to be $91 \mathrm{~J} / \mathrm{g}$ [47]. Degrees of crystallinity and crystallization rates under non-isothermal conditions were determined using circular specimens of approximately $3 \mathrm{mg}$ cut from a $200 \mu \mathrm{m}$ thick compression-molded sheet. These were held at $210^{\circ} \mathrm{C}$ for $1 \mathrm{~min}$ to erase the effects of the prior thermal history, cooled at different rates to $10{ }^{\circ} \mathrm{C}$ and rescanned to $210{ }^{\circ} \mathrm{C}$ at $10 \mathrm{~K} / \mathrm{min}$, in order investigate the subsequent melting behavior.

The tensile behavior of "dog-bone" specimens injection molded from the bulk composites (thickness of $2 \mathrm{~mm}$, gage width of $4 \mathrm{~mm}$ and gage length of $22 \mathrm{~mm}$ ) and the compression behavior of cylindrical specimens with a height of $8 \mathrm{~mm}$ and a diameter of $8 \mathrm{~mm}$ cut from the foams (Fig. 2) were evaluated using a Universal Testing Machine (UTS Test System, Germany) at cross-head speeds of $3 \mathrm{~mm} / \mathrm{min}$ and $0.5 \mathrm{~mm} / \mathrm{min}$, respectively. Three to five specimens were tested for each set of conditions. The Young's moduli, $E_{s}$, of the bulk composites and the compressive moduli, $E^{*}$, of the foams, were evaluated from the initial linear elastic part of stress-strain curves. The tensile strength, $\sigma$, and the compressive strength, $\sigma^{*}$, denoted $\sigma_{e l} *$ in the case of flexible foams and $\sigma_{p l} *$ in the case of plastic foams, were taken to correspond to the first maximum in the stress-strain curves.

\section{Results and discussion}

\subsection{Rheology of the PLLA/nHA blends}

Figure 3 shows the complex viscosity, $\eta^{*}$, of pure PLLA, PLLA $/ 2$ vol\% nHA and PLLA $/ 4.17$ vol\% nHA at $190{ }^{\circ} \mathrm{C}$ as a function of angular frequency, $\omega$. A Newtonian plateau was observed between about $0.3 \mathrm{rad} / \mathrm{s}$ and $10 \mathrm{rad} / \mathrm{s}$ for all the materials, but there was a significant increase in the absolute values of $\eta^{*}$ with increasing nHA content, $\eta^{*}$ more than doubling on addition of 2 vol\% nHA.

\subsection{Dispersion of the nHA in the foam cell walls}

Figure 4 shows TEM micrographs from the cell walls of foams prepared from PLLA/2 and $4.17 \mathrm{vol} \% \mathrm{nHA}$. All the images indicated well dispersed individual nanoparticles, and there was no evidence for particle segregation, such as might have been induced by preferential matrix expansion in regions of locally reduced nHA content, given the dependence of the viscosity on the global nHA content. Moreover, significant numbers of nHA particles were present at the cell wall surfaces, which may contribute both to the hydrophilicity of scaffold and to its osteoconductivity once implanted [1, 20, 21].

\subsection{Foam morphology as a function of nHA content and processing parameters}

Figures 5, 6 show SEM micrographs from the surfaces of PLLA foams containing 0,2 , and $4.17 \mathrm{vol} \%$ of nHA,

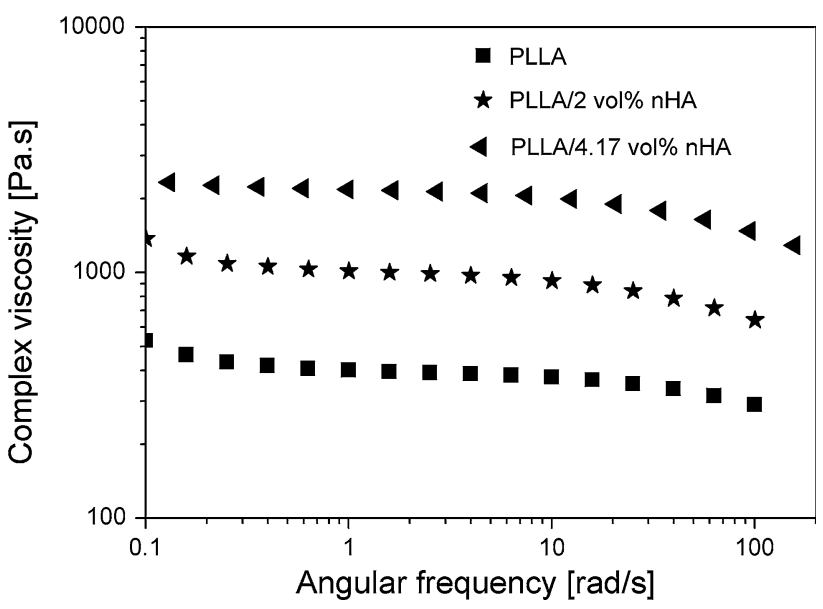

Fig. 3 Complex viscosity, $\eta^{*}$, of PLLA and its nanocomposites at $190{ }^{\circ} \mathrm{C}$ as a function of angular frequency, $\omega$ 
produced under the conditions A to D and E to I, respectively, as described in Table 1. A predominantly open cell structure was observed in all the foams, but the foam architecture and cell diameter varied depending on the nHA content and the processing parameters. Thus, with $P_{\text {sat }}=100 \mathrm{bar}$, the cell diameter decreased from roughly 1-2 $\mathrm{mm}$ for the neat PLLA (Fig. 5a) to $0.8-1 \mathrm{~mm}$ in the presence of nHA (Fig. 5b, c), and with $P_{\text {sat }}=200$ bar (Fig. 5d-1), addition of nHA resulted in a decrease in cell diameter from roughly $0.5-1 \mathrm{~mm}$ to $150-400 \mu \mathrm{m}$. Increasing the nHA content further from 2 to 4.17 vol\% had relatively little effect on the cell diameters under these conditions, although the cell diameters appeared somewhat less uniform at 4.17 vol\% nHA than at 2 vol\% nHA. A similar but less marked trend was observed at $P_{\text {sat }}=250$ bar (Fig. $6 \mathrm{j}-1$ ), the cell diameter decreasing from 150-500 to 100-400 $\mu \mathrm{m}$ as the nHA content was increased. Finally, as shown in Fig. 7, the foam density also tended to increase with increasing nHA content (from 0.13 to $0.19 \mathrm{~g} / \mathrm{cm}^{3}$ for foam D, for example). Limited gas expansion owing to the increase of $\eta^{*}$ with nHA content may explain the reduction in porosity and cell diameter $[11,30$, 32-35]. Moreover, it is known that fillers can act as effective heterogeneous nucleation sites for cell formation, increasing the number of cells per unit volume and leading to a more uniform cell diameter (assuming uniform dispersion of the filler) [34, 48].

The cell diameter may also be inferred from the results in Figs. 5, 6 to decrease with decreasing $T_{\text {sat }}$. For example, the morphologies of foams B and $\mathrm{G}$, processed at different $T_{\text {sat }}\left(175\right.$ and $165^{\circ} \mathrm{C}$, respectively) but similar $P_{\text {sat }}$ (200 bar) and $d P / d t$ (10.65 or 12.2 bar/s) (foam B, Fig. 5df), and foam G, Fig. 6d-f), were significantly different, foams $\mathrm{G}$ showing a more uniform architecture and smaller cell diameters than foam $B$. This may again be be attributed to an increase in viscosity, in this case with decreasing $T_{\text {sat }}$, leading to a decrease in the extent of cell growth and coalescence $[32,33]$. Even so, the densities of foams B and $\mathrm{G}$ were not significantly different.
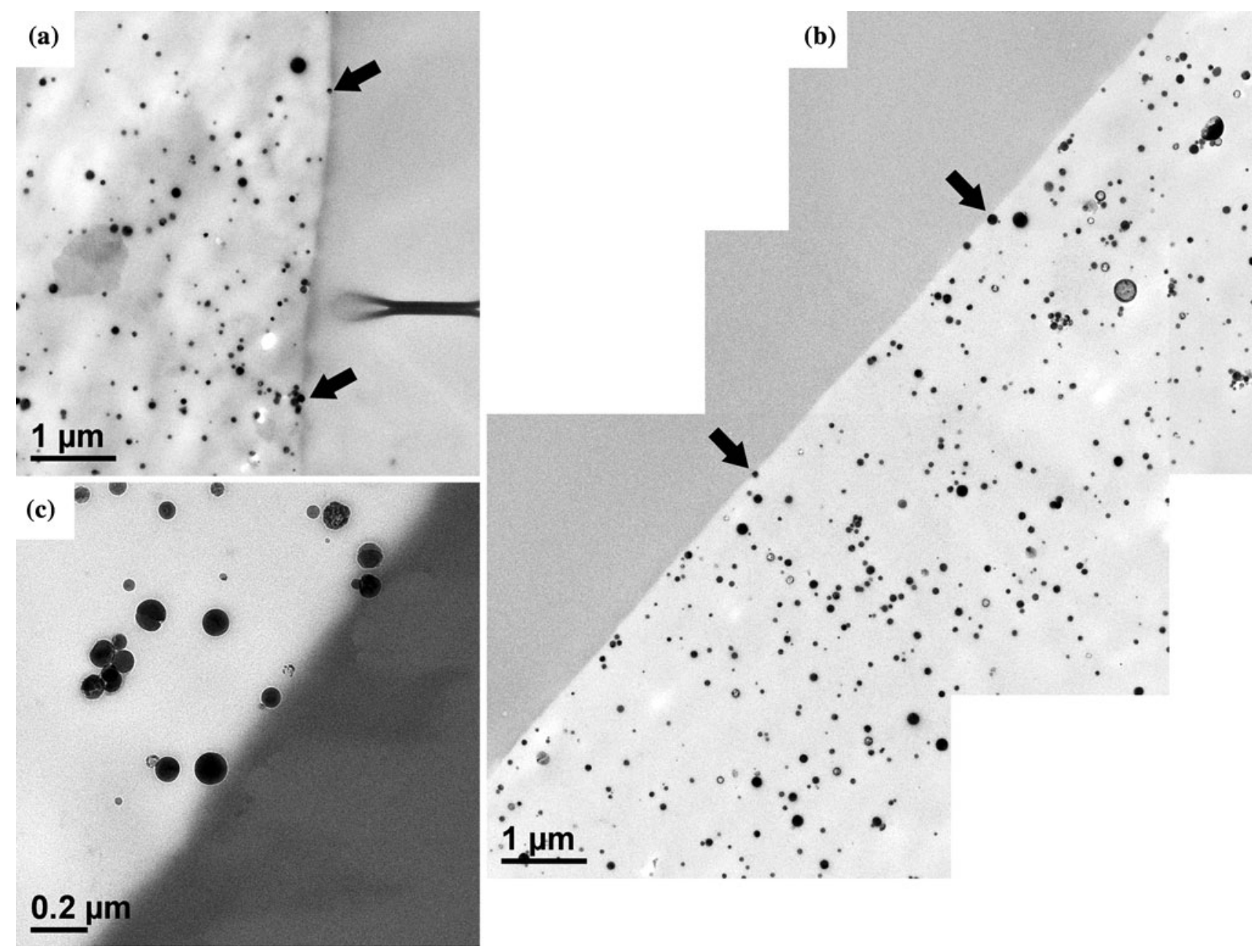

Fig. 4 TEM micrographs of foam wall of a PLLA/2 vol\% nHA and b, $\mathbf{c}$ PLLA/4.17 vol\% nHA. Example of nHA particles at the foam wall surface are indicated by arrows 

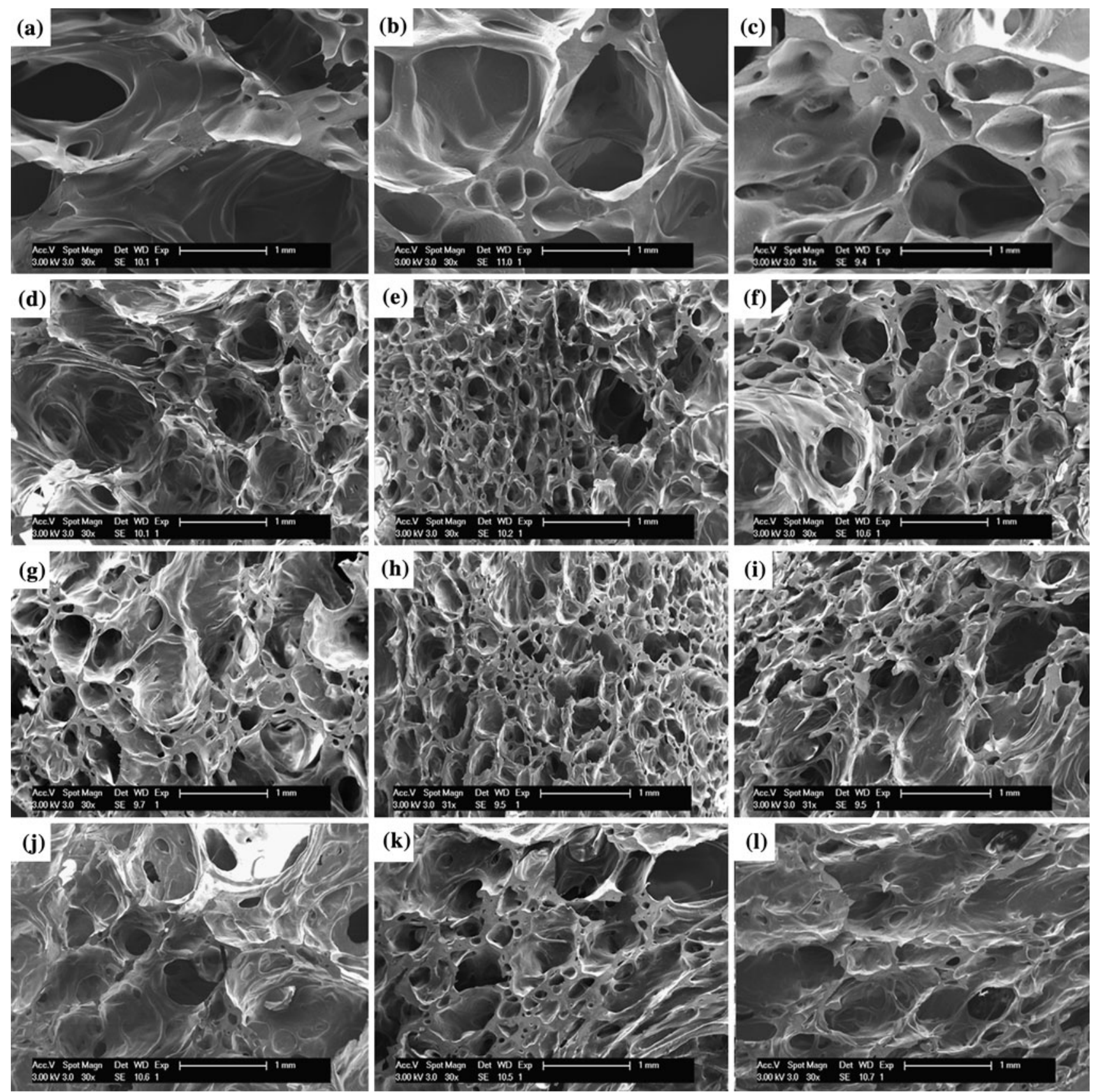

Fig. 5 SEM micrographs of the surface of PLLA foams with 0, 2 and 4.17 vol\% nHA, produced under the conditions shown in Table 1: a-c foam A with 0,2 , and 4.17 vol\% nHA; d-f foam B with 0,2 and

For foams $\mathrm{F}$ and $\mathrm{H}$ (Fig. $6 \mathrm{~d}-\mathrm{f}, \mathrm{j}-\mathrm{l}$ ) and foams $\mathrm{G}$ and $\mathrm{I}$ (Fig. $6 \mathrm{~g}-\mathrm{i}), \mathrm{m}-\mathrm{O}$ ), $T_{\text {sat }}$ and $d P / d t$ were similar, but $P_{\text {sat }}$ varied between 200 and 250 bar. According to Henry's law, the $\mathrm{CO}_{2}$ concentration in the polymer prior to depressurization should be proportional to $P_{\text {sat }}$, so that any increase in $P_{\text {sat }}$ is expected to result in an increased nucleation density for a given depressurization rate and nHA content $[11,30,32,49,50]$. This explains the slightly higher foam densities (Fig. 7) and reduced cell diameters in
4.17 vol $\%$ nHA; $\mathbf{g}-\mathbf{i}$ foam C with 0,2 and 4.17 vol $\%$ nHA; $\mathbf{j}-\mathbf{l}$ foam D with 0,2 and 4.17 vol\% nHA

foams $\mathrm{H}$ and $\mathrm{I}$ compared with those in foams $\mathrm{F}$ and $\mathrm{G}$ (cell diameters of $100-400 \mu \mathrm{m}$ for foam I and $200-500 \mu \mathrm{m}$ for foam $\mathrm{G})[11,51]$. It follows that the low foam densities and large cell diameters in foam A were a consequence of the relatively low $P_{\text {sat }}(100 \mathrm{bar})$ used in this case.

Increasing $d P / d t$ from $10.6 \mathrm{bar} / \mathrm{s}$ (foam B) to $16.5 \mathrm{bar} / \mathrm{s}$ (foam C) at $P_{\text {sat }}=200$ bar and $T_{\text {sat }}=175{ }^{\circ} \mathrm{C}$, did not lead to significant differences in cell diameter and the uniformity of the cell diameters for a given nHA content 

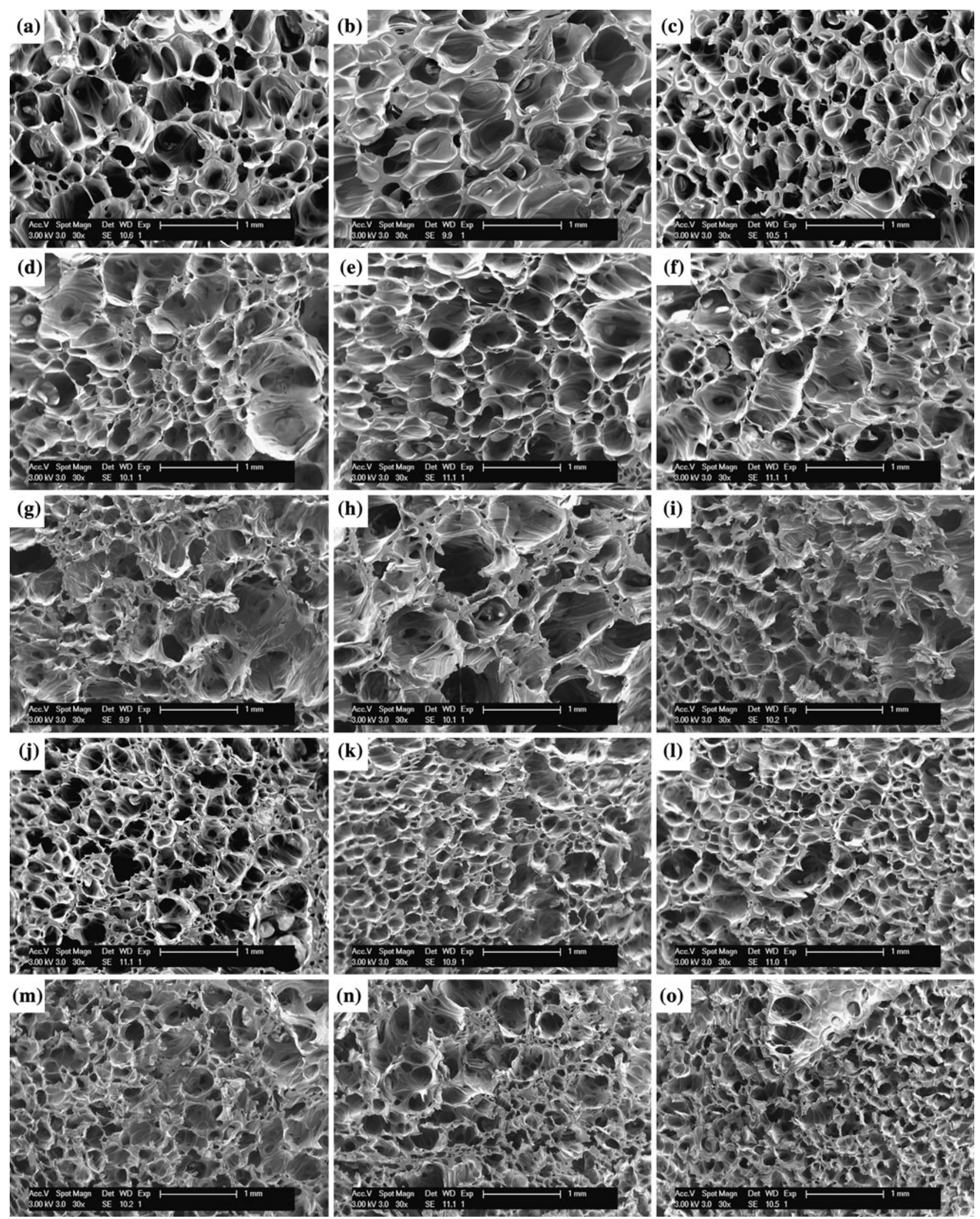

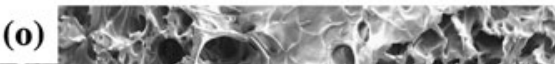

Fig. 6 SEM micrographs of the surface of PLLA foams with 0,2 , and $4.17 \mathrm{vol} \%$ of $\mathrm{nHA}$, produced under the conditions shown in Table 1: a-c foam $\mathrm{E}$ with 0,2 and 4.17 vol\% $\mathrm{nHA}$; d-f foam $\mathrm{F}$ with
0,2 and 4.17 vol\% $\mathrm{nHA} ; \mathbf{g}-\mathbf{i}$ foam G with 0,2 and 4.17 vol\% $\mathrm{nHA}$; j-l foam $\mathrm{H}$ with 0,2 and 4.17 vol\% nHA; m-o foam I with 0,2 and 4.17 vol\% nHA 


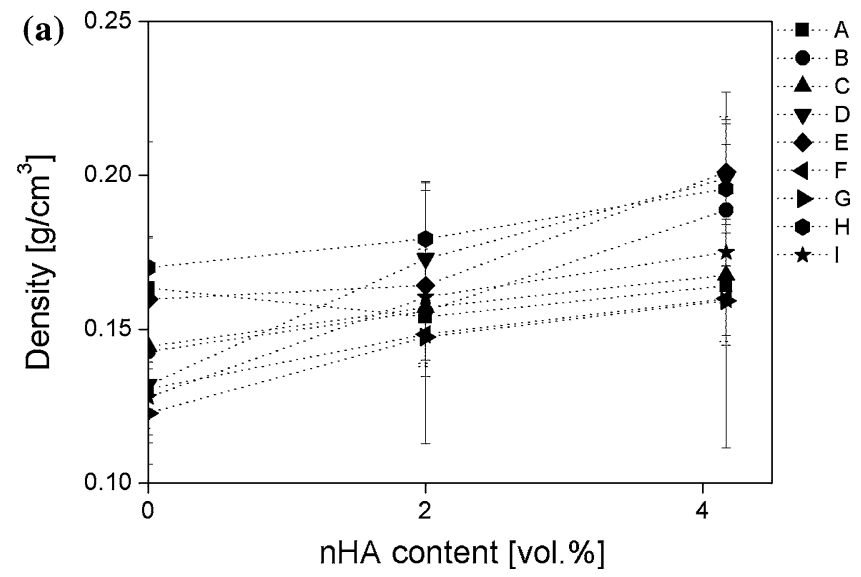

Fig. 7 a Foam densities and $\mathbf{b}$ porosities as a function of nHA content

(compare Fig. 5d, g), Fig. 5e, h), and Fig. 5f, i). However, when the depressurization rate was increased further to $21.1 \mathrm{bar} / \mathrm{s}$ (foam D), the cell diameters increased somewhat and became highly non-uniform in all the materials (Fig. 5j-1). A similar trend was shown by foams E, F and G (Fig. 6), for which an increase in $d P / d t$ from 2.6 to $12.2 \mathrm{bar} / \mathrm{s}$ again led to larger cell diameters and less
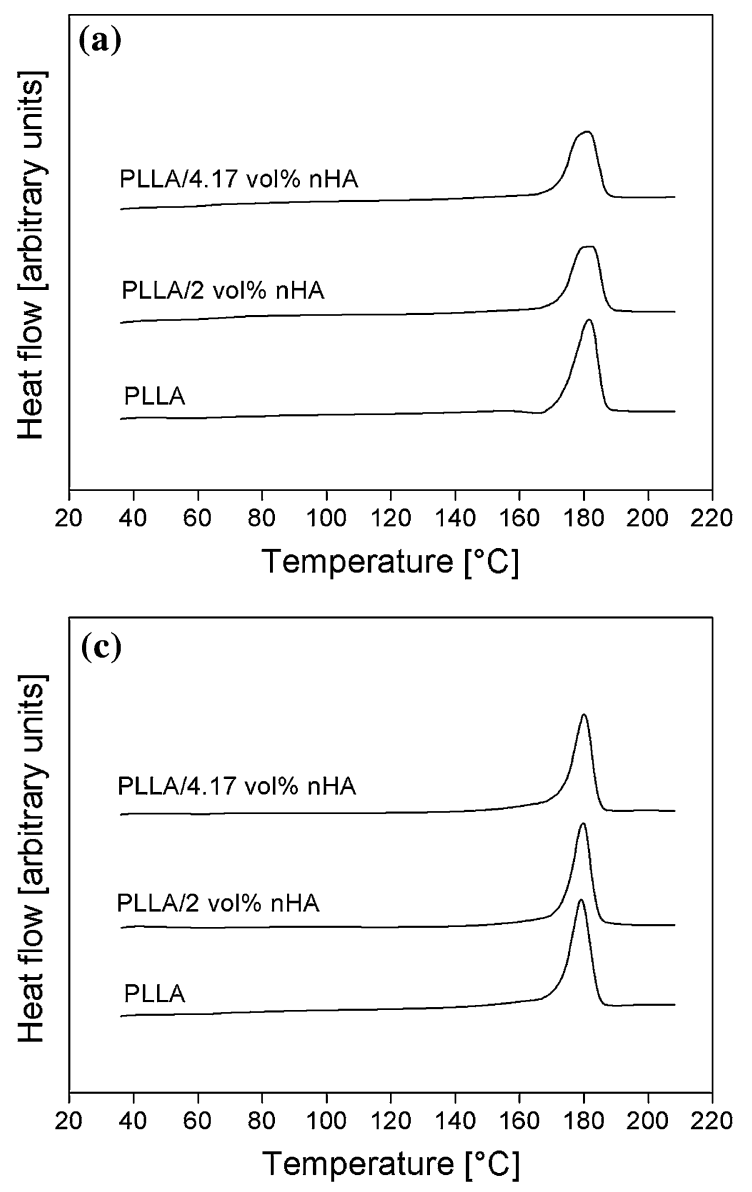

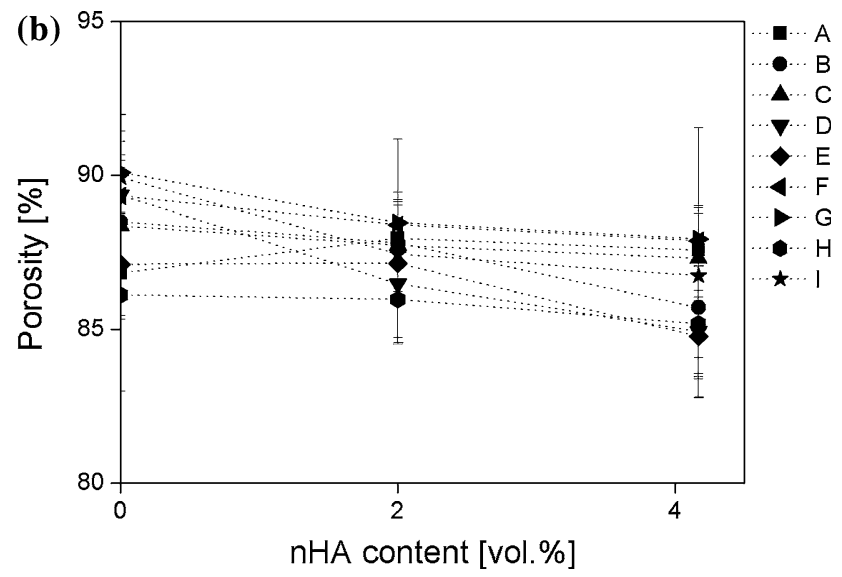

uniform foam architectures. Crystallization during gas release is a possible contributing factor to the smaller cell diameters and more uniform structures obtained at lower $d P / d t$ [26]. At the lowest $d P / d t$, and hence at the lowest cooling rates (cf. Table 1), crystallization in the early stages of gas release may restrict cell growth and stabilize the morphology to a greater extent than at higher cooling
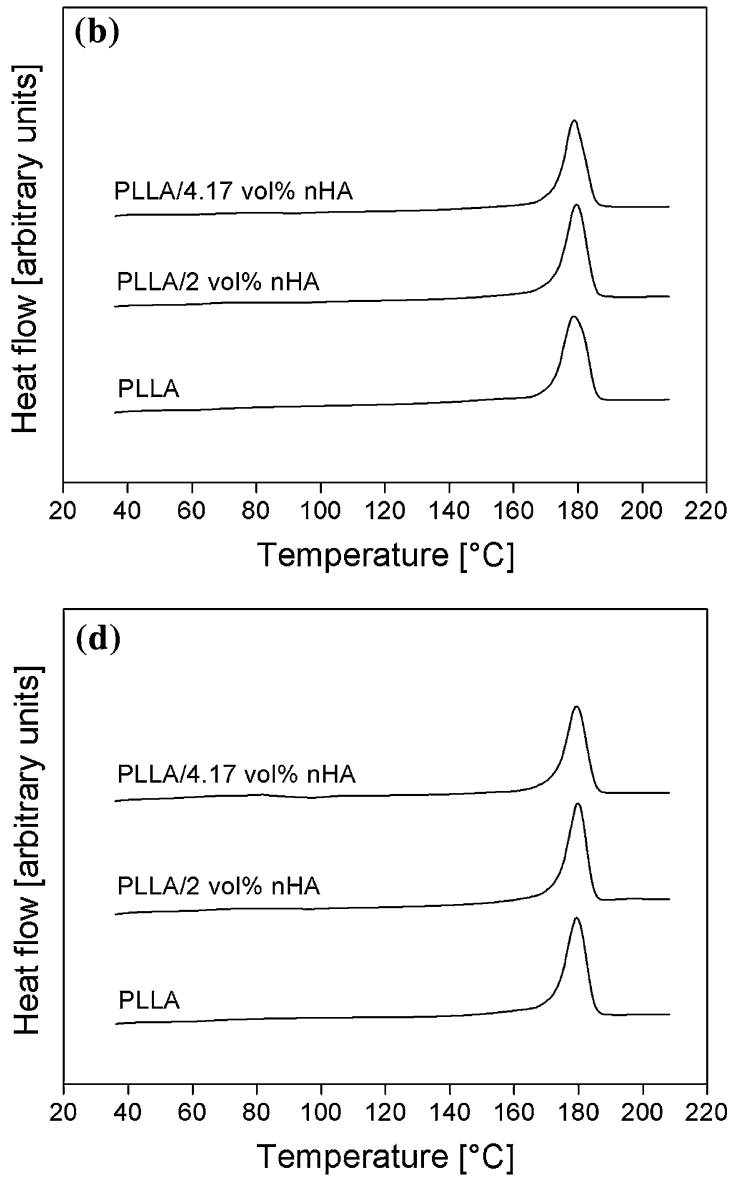

Fig. 8 DSC heating scans of foams a A, b B, c C and d D with the nHA contents indicated 

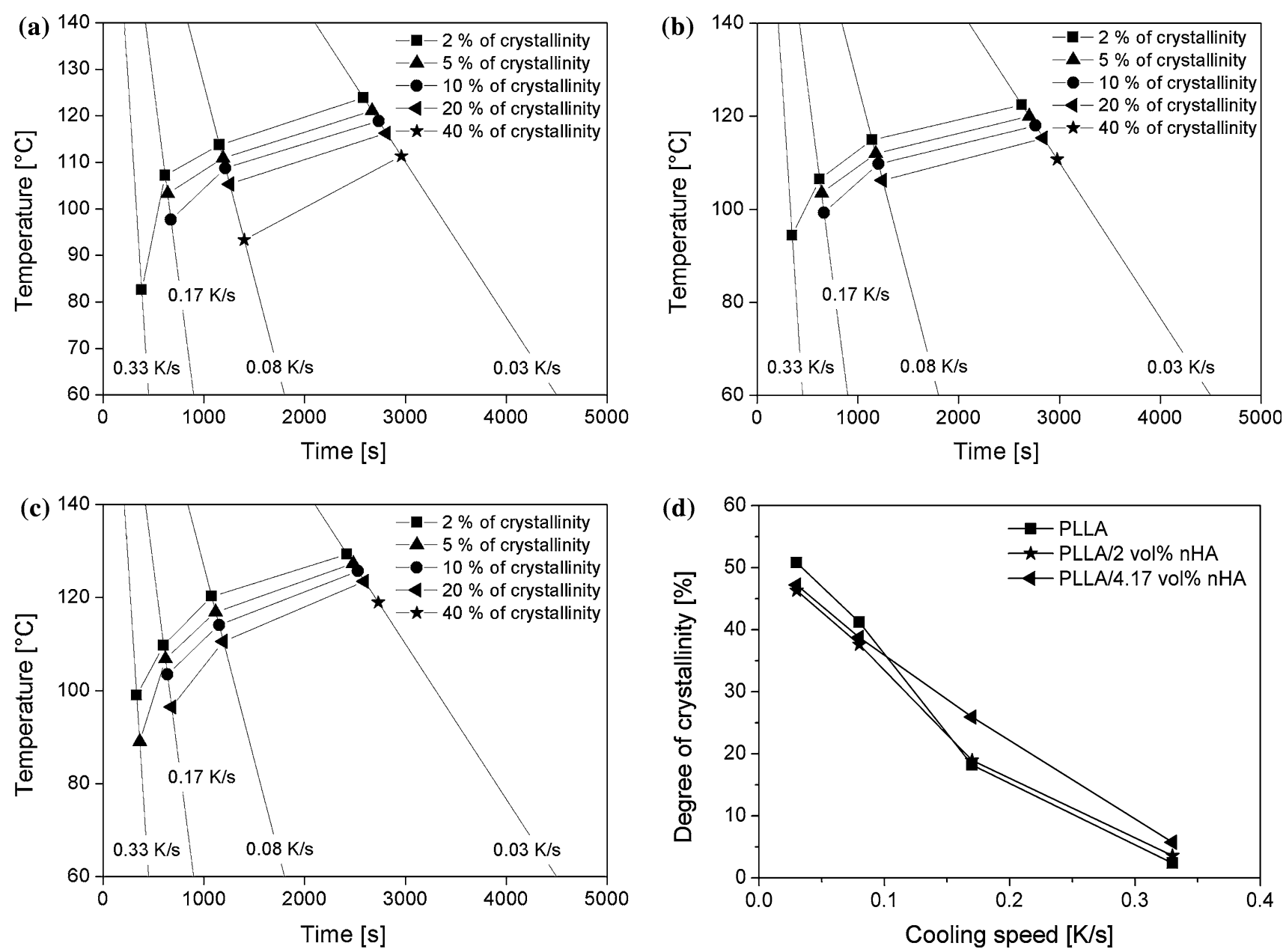

Fig. 9 Continuous-cooling-transformation (CCT) diagrams for a PLLA, b PLLA/2 vol\% nHA, c PLLA/4.17 vol\% nHA, d maximum degree of crystallinity as a function of cooling rate for all materials

rates. The evidence for this will be discussed further below.

\subsection{Crystallization behavior}

Figure 8 shows representative DSC heating scans from foams A to D. Very similar similar melting endotherms were observed in all the foams, with a maximum, $T_{m}$, at $178-180{ }^{\circ} \mathrm{C}$, which was attributed to reorganization and/or recrystallization during the heating scans [52], so that it did not reflect the melting points of the lamellae originally present after solidification. In foams A (Fig. 8a), E and H, however, the main melting peak showed a low temperature shoulder. This was most marked in the presence of nHA and was assumed to reflect the initial presence of relatively stable lamellae in these cases, which correspond to the lowest maximum cooling rates [52-54]. The ContinuousCooling-Transformation (CCT) curves determined independently by DSC shown in Fig. 9a-c) give the degree of crystallinity as a function of time and cooling rate.
Crystallization generally occurred somewhat more rapidly in the presence of nHA, owing to a small but significant increase in the density of spherulite nucleation at a given temperature or cooling rate [39]. The CCT curves were assumed to provide some indication of the crystallization rates during the foaming process, although one should bear in mind: (i) the possible plasticizing effect of residual dissolved $\mathrm{CO}_{2}$ after depressurization [41, 55, 56]; (ii) that the temperatures measured inside the autoclave did not necessarily give a precise indication of the local temperatures within the PLA; (iii) the influence of deformation on the crystallization rates [55, 57]. For the range of cooling rates investigated, i.e. between 1.2 and $5.6 \mathrm{~K} / \mathrm{s}$ from $T_{\text {sat }}$ to $110{ }^{\circ} \mathrm{C}$ and between 0.02 and $0.05 \mathrm{~K} / \mathrm{s}$ below $110^{\circ} \mathrm{C}$ for all foams, Fig. 9 suggests that there should be little crystallization above $110{ }^{\circ} \mathrm{C}$ in the quiescent state in the absence of $\mathrm{CO}_{2}$. On the other hand, crystallization is expected to occur readily below about $110{ }^{\circ} \mathrm{C}$, given that it was observed in this temperature range in the DSC measurements even at relatively high cooling rates. Lamellae 

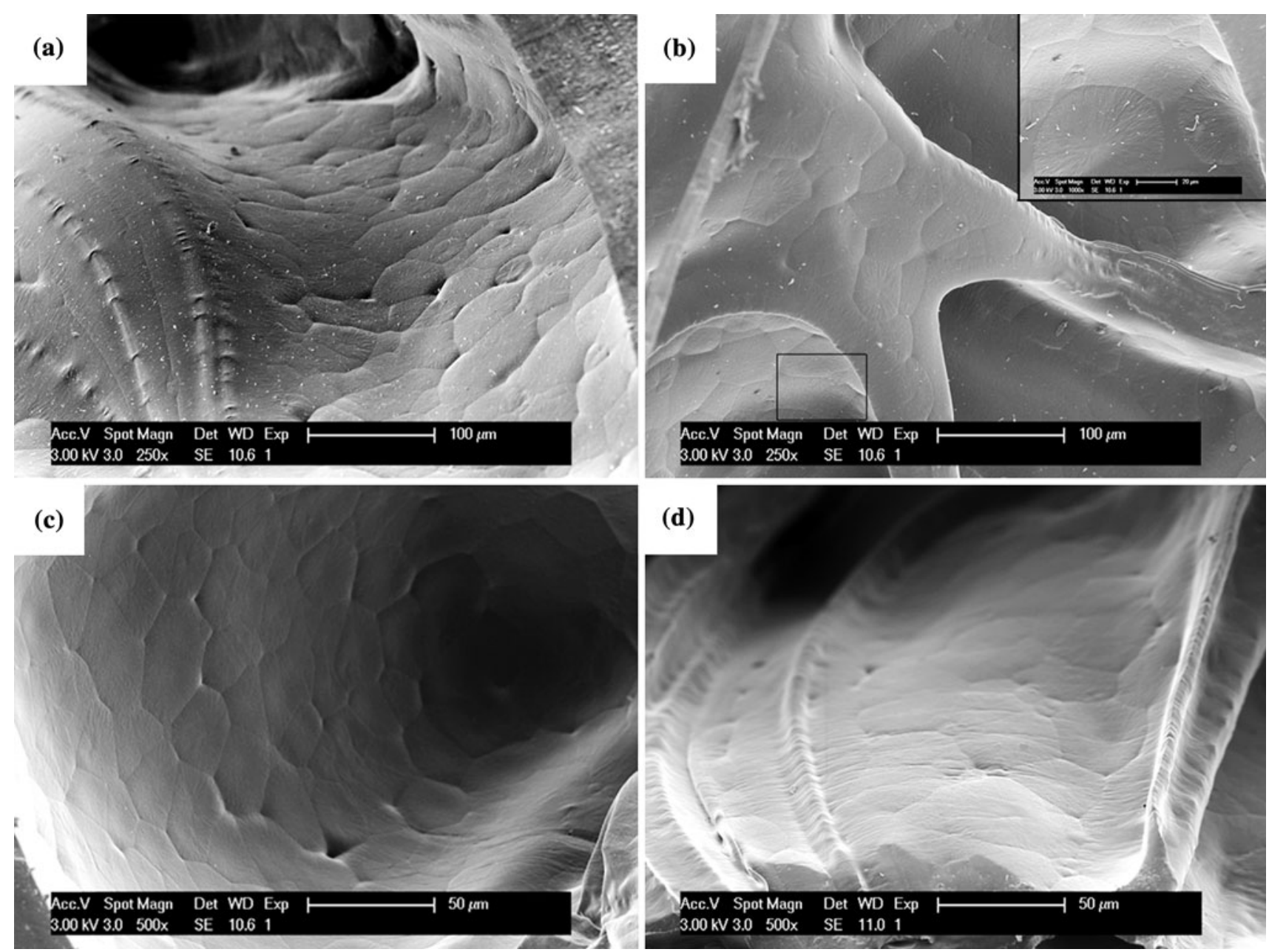

Fig. 10 SEM micrographs of a neat PLLA foam A, b neat PLLA foam B, c PLLA/4.17 vol\% nHA foam E, d PLLA/2 vol\% nHA foam H
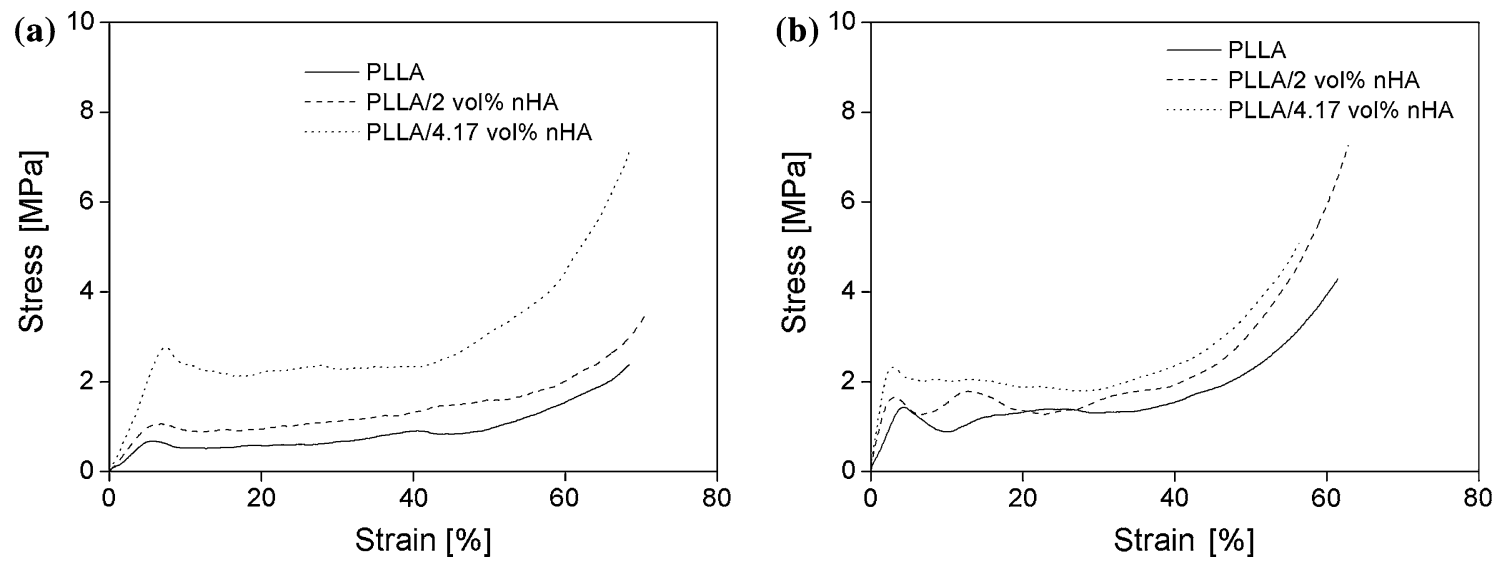

Fig. 11 Representative compressive stress-strain curves for foams a B and b E with the nHA contents indicated

formed under these conditions, i.e. at high degrees of supercooling, are relatively unstable and hence prone to reorganization and/or recrystallization during heating, consistent with the DSC traces in Fig. 8 [39]. In the case of foam $\mathrm{A}$, the small exotherm in the temperature range immediately below the main melting peak in the absence of nHA (Fig. 8a), characteristic of a transformation from the less stable $\alpha^{\prime}$ crystalline phase of PLLA to the $\alpha$ phase during the scans, was again consistent with a crystallization temperature $\leq 110^{\circ} \mathrm{C}$ [39]. Indeed, very similar thermal 
Table 2 Tensile modulus and yield strength of the bulk moldings

\begin{tabular}{lll}
\hline & $\begin{array}{l}\text { Young's Modulus, } \\
E_{s},(\mathrm{MPa})\end{array}$ & $\begin{array}{l}\text { Yield strength, } \\
\sigma,(\mathrm{MPa}]\end{array}$ \\
\hline PLLA & $3133 \pm 328$ & $58.7 \pm 2.3$ \\
PLLA/2 vol\% nHA & $3135 \pm 227$ & $58.7 \pm 1.4$ \\
PLLA/4.17 vol\% nHA & $3242 \pm 198$ & $57.9 \pm 1.0$ \\
\hline
\end{tabular}

melting transitions were observed in a previous study, in which PLLA/nHA films were crystallized isothermally at $110{ }^{\circ} \mathrm{C}$ [58]. The DSC measurements did not reveal any clear dependence of $X_{c}$ on nHA content or processing parameters, the measured $X_{c}$ showing considerably more experimental scatter (standard deviation of about $\pm 5 \%$ ) than systematic variation. The mean $X_{c}$ was about $57 \%$, broadly consistent with $X_{c}$ of about $50 \%$ obtained after cooling PLLA and its nanocomposites at comparable rates in the DSC (Fig. 9d).

SEM indicated transcrystallinity and equiaxed spherulites to coexist for all the nHA contents and processing conditions investigated (Fig. 10). The transcrystalline regions were suggestive of deformation-induced crystallization [59], taking place during, or immediately after foam expansion, and hence to contribute to the overall structural integrity of foams at high temperatures as suggested previously. It follows that the equiaxed spherulites, which were generally dominant, were formed well after foam expansion in the relatively low cooling rate regime at $110{ }^{\circ} \mathrm{C}$ and below. As shown in the inset to Fig. 10b, local regions of the foams in which apparently amorphous regions of PLLA subsisted between spherulites were also occasionally encountered, accounting for the large scatter in the measured $X_{c}$.

\subsection{Compression tests}

Representative compressive stress-strain curves, indicating elastic-plastic deformation in each case according to the classification of Gibson and Ashby, are given in Fig. 11 $[60,61]$. The foams showed increased compression modulus $E^{*}$ and compressive strength $\sigma^{*}$ with increasing nHA content, but increasing the nHA content also tended to decrease the porosity as seen in Fig. 7. To assess the influence of these changes in porosity, the dependence of $E^{*}$ and $\sigma^{*}$ on relative density were modeled following Gibson and Ashby [61]. For an isotropic cell structure,

$\frac{E^{*}}{E_{S}}=C_{1} \emptyset^{2}\left(\frac{\rho^{*}}{\rho_{S}}\right)^{2}+(1-\emptyset)\left(\frac{\rho^{*}}{\rho_{S}}\right)$.

where $C_{1}$ is a constant of the order of one, $E_{s}$ is the Young's modulus of the matrix (Table 2) and $\rho^{*}$ and $\rho_{s}$ are
Fig. 12 a Compressive modulus $\left(E^{*}\right)$ and b compressive strength $\left(\sigma^{*}\right)$ for all the foams. In (a), the data are compared with the predictions of the Gibson model for open and closed cells. In (b), the data are compared with the predictions of the Gibson model for flexible and plastic foams
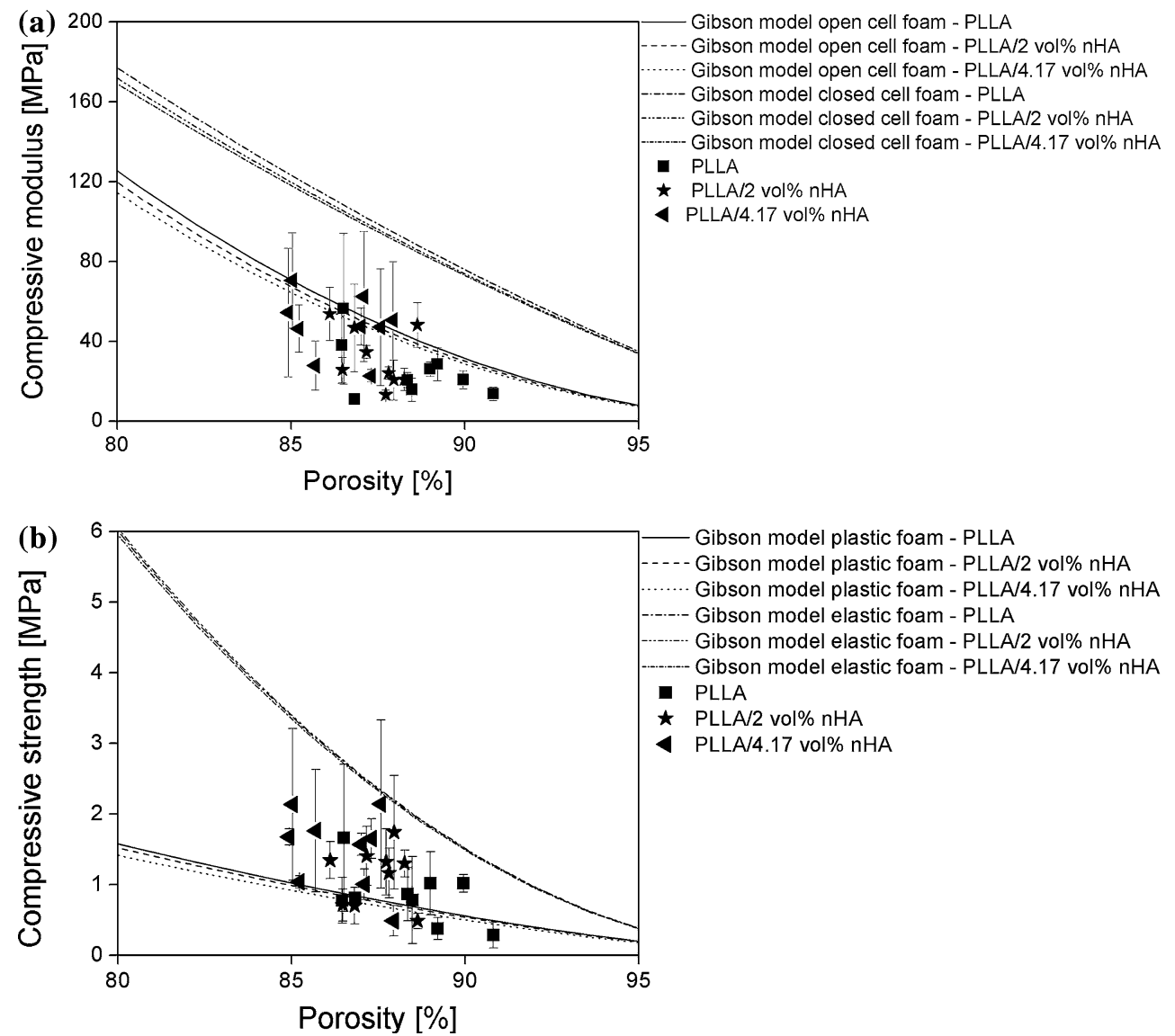
Table 3 Structural parameters of foam E with 4.17 vol\% nHA measured by $\mu \mathrm{CT}$

\begin{tabular}{llllll}
\hline Porosity, $\varepsilon^{*}(\%)$ & Open porosity, $\varepsilon^{*}(\%)$ & Specific surface $(1 / \mathrm{mm})$ & Degree of anisotropy & Cell diameter $(\mu \mathrm{m})$ & Cell wall thickness $(\mu \mathrm{m})$ \\
\hline $76.97 \pm 2.06$ & $76.96 \pm 2.03$ & $32.9 \pm 2.22$ & $2.71 \pm 0.30$ & $362 \pm 50.6$ & $115 \pm 7.34$ \\
\hline
\end{tabular}
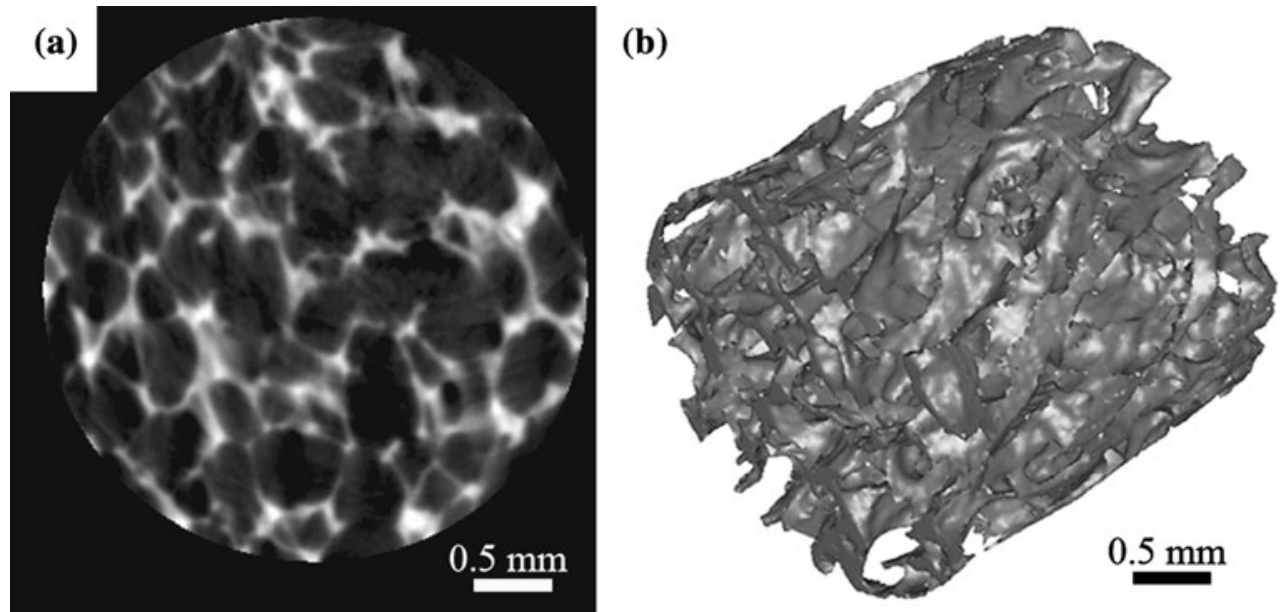

Fig. 13 a 2D slice perpendicular to the foaming direction and b 3D $\mu \mathrm{CT}$ reconstruction of foam $\mathrm{E}$ with 4.17 vol\% nHA

the foam and matrix densities respectively. The fraction of solid in the cell edges, $\varnothing$ (the remaining fraction, $1-\varnothing$, is in the cell walls), was defined to be equal to one for opencelled foams and was taken to be 0.8 for closed-cell foams ( $20 \%$ of the solid in the cell walls), based on typical values for closed-cell foams from the literature [62, 63]).

For a flexible foam, which shows extensive non-linear elasticity owing to elastic buckling of the cell walls, the dependence of $\sigma^{*}$ (denoted $\sigma_{e l}{ }^{*}$ ) on relative density is given by

$\frac{\sigma_{e l}^{*}}{E_{S}}=0.05\left(\frac{\rho^{*}}{\rho_{S}}\right)^{2}$

For a plastic foam, in which the cell walls yield plastically, the dependence of $\sigma^{*}\left(\operatorname{denoted} \sigma_{p l}{ }^{*}\right)$ on relative density is given by

$\frac{\sigma_{p l}^{*}}{\sigma}=0.3\left(\frac{\rho^{*}}{\rho_{S}}\right)^{3 / 2}$.

$E^{*}$ and $\sigma^{*}$ are shown in Fig. 12 for the various foams. The data for $E^{*}$ (Fig. 12a) were closer to the predictions of Gibson and Ashby's model for open-cell foams than for closed-cell foams, assuming constant $E_{s}$ (Eq. 5), consistent with the SEM observations of predominantly open-cell structures (Figs. 5, 6). Moreover, the similar dependence of $E^{*}$ on porosity in all the foams indicated the nHA to have little effect on $E^{*}$, as expected given the very minor influence of nHA on $E_{s}$ implied by the tensile test results in Table 2 .

The trends in the compressive strength of the foams (Fig. 12b) were less clear, the experimental data for $\sigma^{*}$ generally being intermediate between the model predictions for flexible and plastic foam models. Nevertheless, $\sigma^{*}$ was clearly correlated with the porosity, again suggesting the nanoparticles to have a minor influence. This contrasts with results obtained elsewhere for polypropylene foams modified with layered silicate clay, for example, addition of $2 \mathrm{wt} \%$ clay leading to an increase in compression modulus from $0.44-1.72 \mathrm{MPa}$ at approximately constant foam density [64]. Similar improvements in modulus have been reported in polyurethane/clay nanocomposite foams and polystyrene/carbon nanofiber nanocomposite foams $[29,65]$. However, in all these materials, the filler aspect ratios were relatively high (platelets or fibers), and one would therefore expect a relatively high degree of reinforcement compared with the present case of spherical particles.

\subsection{Suitability of the foams for bone replacement}

It is generally considered than an ideal scaffold for the growth of new bone tissue should be a three-dimensional network with inter-connected pores. As stated in the introduction, a porosity in the range of 50-90\% and cell diameters in the range $200-500 \mu \mathrm{m}$ are known to promote the migration of cells and bone growth within the scaffold [5]. The foams in the present study generally showed porosities between 85 and $90 \%$ (Fig. 7b) and an interconnected morphology, as shown in Figs. 5 and 6. The cell diameters and homogeneity of the structures varied considerably, but could be tuned by adjusting the foaming 
parameters. In the present case, PLLA $/ 4.17$ vol\% nHA foam $\mathrm{E} \quad\left(P_{\text {sat }}=200 \mathrm{bar}, \quad T_{\text {sat }}=165^{\circ} \mathrm{C}\right.$ and $d P /$ $d t=2.6$ bars $/ \mathrm{s}$ ) was considered to be the most promising structure for further investigation, showing cell diameters in the range 300-500 $\mu \mathrm{m}$ and a homogenous structure, and the highest concentration of nHA achievable with the present processing route. The morphological parameters of foam $\mathrm{E}$ with 4.17 vol\% of nHA were investigated further by $\mu \mathrm{CT}$ analysis, as summarized in Table 3 and Fig. 13, which shows a $2 \mathrm{D}$ slice and a $3 \mathrm{D}$ reconstruction of a representative sample from the foam. The mean cell diameter obtained by $\mu \mathrm{CT}$ was consistent with cell diameters determined from SEM micrographs. The porosity was lower than calculated from the density measurements (77 as opposed to $85 \%$ ), but was still well within the required range, and the dominance of open porosity suggested by the SEM observations was confirmed. The structure also showed significant anisotropy, as reflected by a measured degree of anisotropy, defined as the ratio between the maximal and minimal radius of the mean intercept length (MIL) ellipsoid, of 2.7 (Table 3), and the 3D reconstruction in Fig. 13, in which elongated pores oriented in the foaming direction are visible, reminiscent of the morphology of trabecular bone $[12,66]$.

The compressive modulus of foam $\mathrm{E}$ with $4.17 \mathrm{vol} \%$ of nHA of $70 \mathrm{MPa}$ was within the range of values cited for trabecular bone (50-500 MPa), although the compressive strength was somewhat lower (2.2 $\mathrm{MPa}$ as compared with 7-10 MPa for trabecular bone) [1, 8, 66-68]. The main goal of adding nanoparticles in PLLA was not to improve the mechanical properties, however, but to enhance bioactivity, and biomechanical studies have already proven the feasibility of using scaffolds with relatively modest mechanical properties in clinical applications, such as revision knee arthroplasty [69]. Moreover, significant increases in both the modulus and compressive strength may be obtained, if necessary, by incorporating continuous biodegradable glass fibers into the foams [13, 14].

Owing to the lack of effective temperature control in the critical regime for crystallization in the present set-up, the matrix morphology was found to be relatively insensitive to the processing conditions, spherulitic microstructures and relatively high degrees of crystallinity being obtained throughout. It was consequently difficult to assess directly the extent to which crystallization was determinant for the formation of stable foam structures and it will be difficult on this basis to determine whether a spherulitic microstructure is ideal for the in vitro and in vivo response of the foams. While amorphous PLLA crystallizes relatively rapidly under physiological conditions, the initial degree of crystallinity has been shown to be an important factor for the degradation rate of PLLA [58, 70-72]. Moreover, as shown in our previous work on PLLA/nHA films, coarse spherulitic microstructures may result in more brittle behavior after aging in vitro than initially amorphous films that undergo cold crystallization during ageing, which results in relatively homogeneous microstructures [58]. On the other hand, it is not known whether this represents a critical limitation for the application, and in vitro and in vivo testing will be necessary to establish whether better microstructural control is a practical requirement.

\section{Conclusions}

The aim of this study was to investigate the extent to which the presence of nHA nanoparticles and foaming parameters influence the morphology, crystallinity and mechanical properties of PLLA/nHA nanocomposite foams intended for use as bone replacement scaffolds. It was shown that nHA addition resulted in a reduced cell size and more homogeneous architecture, which were attributed to an increased matrix viscosity and/or an increased cell nucleation density. Increasing $P_{\text {sat }}$ also resulted in a reduced cell size, again attributed to an increased nucleation density, in this case due to the higher $\mathrm{CO}_{2}$ content prior to depressurization. Decreasing $T_{\text {sat }}$ induced a more uniform architecture and a reduced cell size, again due to an increased matrix viscosity and, finally, decreasing $d P / d t$ improved the stability of the structure and reduced the cell size. SEM indicated transcrystallinity and equiaxed spherulites to coexist for all the nHA contents and processing conditions investigated, and the high degree of crystallinity of all the foams was consistently high. This was argued to be due to the insensitivity of the effective cooling rates in the temperature range at which crystallization took place to the process parameters. Given the lack of influence of the nHA on the matrix mechanical properties, the compressive modulus and strength of the foams were therefore determined primarily by the degree of porosity.

Foams produced from PLLA/4.17 vol\% nHA at $P_{\text {sat }}$ 200 bar with depressurization rates of $2.6 \mathrm{bar} / \mathrm{s}$ were considered to be the most suitable for bone replacement on the basis of their morphological parameters, showing interconnected porosity of about $76 \%$ as measured by $\mu \mathrm{CT}$, cell diameters in the 200-500 $\mu \mathrm{m}$ range and a homogeneous structure. The next stage of the work will focus on evaluating the biocompatibility through in vitro investigations of the influence of the nHA content on the deposition of calciumcontaining minerals and the cell response. It will also be important to verify whether the biological activity of the PLLA/nHA foam is maintained during resorption.

Acknowledgments The authors gratefully acknowledge funding from the Faculty of Engineering Science (STI), EPFL and the technical assistance of the Interdisciplinary Centre for Electron Microscopy (CIME) of the EPFL. The authors would also like to thank Prof. 
Pioletti of the Laboratory of Biomechanical Orthopedics (LBO) of the EPFL for helpful discussions.

\section{References}

1. Murugan R, Ramakrishna S. Development of nanocomposites for bone grafting. Composites Science and Technology. 2005;65(1516 SPEC. ISS.):2385-406.

2. Davies JE. Bone Engineering. Davies JE, ed. Toronto: University of Toronto Press; 2000.

3. Albrektsson T, Johansson C. Osteoinduction, osteoconduction and osseointegration. Eur Spine J. 2001;10(SUPPL. 2).

4. An YH, Woolf SK, Friedman RJ. Pre-clinical in vivo evaluation of orthopaedic bioabsorbable devices. Biomaterials. 2000;21(24):2635-52.

5. Karageorgiou V, Kaplan D. Porosity of 3D biomaterial scaffolds and osteogenesis. Biomaterials. 2005;26(27):5474-91.

6. Middleton JC, Tipton AJ. Synthetic biodegradable polymers as orthopedic devices. Biomaterials. 2000;21(23):2335-46.

7. Gupta B, Revagade N, Hilborn J. Poly(lactic acid) fiber: an overview. Prog Polym Sci. 2007;32(4):455-82.

8. Rezwan K, Chen QZ, Blaker JJ, Boccaccini AR. Biodegradable and bioactive porous polymer/inorganic composite scaffolds for bone tissue engineering. Biomaterials. 2006;27(18):3413-31.

9. Mano Jf, Sousa RA, Boesel LF, Neves NM, Reis RL. Bioinert, biodegradable and injectable polymeric matrix composites for hard tissue replacement: state of the art and recent developments. Compos Sci Technol. 2004;64(6):789-817.

10. Burg KJL, Porter S, Kellam JF. Biomaterial developments for bone tissue engineering. Biomaterials. 2000;21(23):2347-59.

11. Mathieu LM, Montjovent MO, Bourban PE, Pioletti DP, Manson JAE. Bioresorbable composites prepared by supercritical fluid foaming. J Biomed Mater Res. 2005;75(1):89-97.

12. Mathieu LM, Mueller TL, Bourban PE, Pioletti DP, Muller R, Manson JA. Architecture and properties of anisotropic polymer composite scaffolds for bone tissue engineering. Biomaterials. 2006;27(6):905-16.

13. Bühler M, Bourban PE, Manson JAE. Cellular composites based on continuous fibres and bioresorbable polymers. Compos A Appl Sci Manuf. 2008;39(12):1779-86.

14. Bühler M, Bourban PE, Manson JAE. Cellular thermoplastic composites with microstructural gradients of fibres and porosity. Compos Sci Technol. 2008;68(3-4):820-8.

15. Higashi S, Yamamuro T, Nakamura T. Polymer-hydroxyapatite composites for biodegradable bone fillers. Biomaterials. 1986; 7(3):183-7.

16. Zambonin G, Grano M. Biomaterials in orthopaedic surgery: effects of different hydroxyapatites and de-mineralized bone matrix on proliferation rate and bone matrix synthesis by human osteoblasts. Biomaterials. 1995;16(5):397-402.

17. Weiner S, Traub W. Bone structure: from angstroms to microns. FASEB J. 1992;6(3):879-85.

18. Weiner S, Wagner HD. The material bone: structure-mechanical function relations. Annu Rev Mater Sci. 1998;28(1):271-98.

19. Posner AS. Crystal chemistry of bone mineral. Physiol Rev. 1969;49(4):760-92.

20. Webster TJ, Ergun C, Doremus RH, Siegel RW, Bizios R. Enhanced functions of osteoblasts on nanophase ceramics. Biomaterials. 2000;21(17):1803-10.

21. Kim HW. Biomedical nanocomposites of hydroxyapatite/polycaprolactone obtained by surfactant mediation. J Biomed Mater Res. 2007;83(1):169-77.

22. Nam YS, Park TG. Porous biodegradable polymeric scaffolds prepared by thermally induced phase separation. J Biomed Mater Res. 2006;47:8-17.
23. Kim HW, Kim HE, Knowles JC. Production and potential of bioactive glass nanofibers as a next-generation biomaterial. Adv Funct Mater. 2006;16(12):1529-35.

24. Jung Y, Kim SS, Kim YH, Kim SH, Kim BS, Kim S, et al. A poly(lactic acid)/calcium metaphosphate composite for bone tissue engineering. Biomaterials. 2005;26(63):14-22.

25. Forman S, Káš J, Fini F, Steinberg M, Ruml T. The effect of different solvents on the ATP/ADP content and growth properties of HeLa cells. J Biochem Mol Toxicol. 1999;13(1):11-5.

26. Mihai M, Huneault MA, Favis BD. Crystallinity development in cellular poly(lactic acid) in the presence of supercritical carbon dioxide. J Appl Polym Sci. 2009;113(5):2920-32.

27. Jacobs LJM, Kemmere MF, Keurentjes JTF. Sustainable polymer foaming using high pressure carbon dioxide: a review on fundamentals, processes and applications. Green Chem. 2008; 10(7):731-8.

28. Reverchon E, Adami R, Cardea S, Porta GD. Supercritical fluids processing of polymers for pharmaceutical and medical applications. J Supercrit Fluids. 2009;47(3):484-92.

29. Lee LJ, Zeng C, Cao X, Han X, Shen J, Xu G. Polymer nanocomposite foams. Compos Sci Technol. 2005;65(15-16): 2344-63.

30. Kang DJ, Xu D, Zhang ZX, Pal K, Bang DS, Kim JK. Wellcontrolled microcellular biodegradable PLA/Silk composite foams using supercritical $\mathrm{CO}_{2}$. Macromol Mater Eng. 2009; 294(9):620-4.

31. Fujimoto Y, Sinha Ray S, Okamoto M, Ogami A, Yamada K, Ueda K. Well-controlled biodegradable nanocomposite foams: from microcellular to nanocellular. Macromol Rapid Commun. 2003;24(7):457-61.

32. Ema Y, Ikeya M, Okamoto M. Foam processing and cellular structure of polylactide-based nanocomposites. Polymer. 2006; 47(15):5350-9.

33. Strauss W, D'Souza NA. Supercritical CO2 processed polystyrene nanocomposite foams. J Cell Plast. 2004;40(3):229-41.

34. Nam PH, Maiti P, Okamoto M, Kotaka T, Nakayama T, Takada $\mathrm{M}$, et al. Foam processing and cellular structure of polypropylene/ clay nanocomposites. Polym Eng Sci. 2002;42(9):1907-18.

35. Di Y, Iannace S, Di Maio E, Nicolais L. Poly(lactic acid)/organoclay nanocomposites: thermal, rheological properties and foam processing. J Polym Sci, Part B: Polym Phys. 2005; 43(6):689-98.

36. Zeng C, Han X, Lee LJ, Koelling KW, Tomasko DL. Polymerclay nanocomposite foams prepared using carbon dioxide. Adv Mater. 2003;15(20):1743-7.

37. Maiti P, Nam PH, Okamoto M, Hasegawa N, Usuki A. Influence of crystallization on intercalation, morphology, and mechanical properties of polypropylene/clay nanocomposites. Macromolecules. 2002;35(6):2042-9.

38. Zhang QX, Yu ZZ, Xie XL, Mai YW. Crystallization and impact energy of polypropylene/ $\mathrm{CaCO}_{3}$ nanocomposites with nonionic modifier. Polymer. 2004;45(17):5985-94.

39. Delabarde C, Plummer CJG, Bourban PE, Månson JAE. Solidification behavior of PLLA/nHA nanocomposites. Compos Sci Technol. 2010;70(13):1813-9.

40. Mathieu LM, Bourban PE, Manson JAE. Processing of homogeneous ceramic/polymer blends for bioresorbable composites. Compos Sci Technol. 2006;66(11-12):1606-14.

41. Takada M, Hasegawa S, Ohshima M. Crystallization kinetics of poly(L-lactide) in contact with pressurized $\mathrm{CO}_{2}$. Polym Eng Sci. 2004;44(1):186-96.

42. Takada M, Tanigaki M, Ohshima M. Effects of $\mathrm{CO}_{2}$ on crystallization kinetics of polypropylene. Polym Eng Sci. 2001; 41(11):1938-46.

43. Roshan-Ghias A, Terrier A, Bourban PE, Pioletti DP. In vivo cyclic loading as a potent stimulatory signal for bone formation 
inside tissue engineering scaffolds. Eur Cells Mater. 2010; 19:41-9.

44. Van Der Pol U, Mathieu L, Zeiter S, Bourban PE, Zambelli PY, Pearce SG, et al. Augmentation of bone defect healing using a new biocomposite scaffold: an in vivo study in sheep. Acta Biomater. 2010;6(9):3755-62.

45. Lee MJ, Sohn SK, Kim KT, Kim CH, Ahn HB, Rho MS, et al. Effect of hydroxyapatite on bone integration in a rabbit tibial defect model. Clin Orthop Surg. 2010;2(2):90-7.

46. Monfoulet L, Rabier B, Chassande O, Fricain JC. Drilled hole defects in mouse femur as models of intramembranous cortical and cancellous bone regeneration. Calcif Tissue Int. 2010; 86(1):72-81.

47. Pyda M, Bopp RC, Wunderlich B. Heat capacity of poly(lactic acid). J Chem Thermodyn. 2004;36(9):731-42.

48. Colton JS, Suh NP. Nucleation of microcellular thermoplastic foam with additives: part i: theoretical considerations. Polym Eng Sci. 1987;27(7):485-92.

49. Park CB, Cheung LK. A study of cell nucleation in the extrusion of polypropylene foams. Polym Eng Sci. 1997;37(1):1-10.

50. Teng X, Ren J, Gu S. Preparation and characterization of porous PDLLA/HA composite foams by supercritical carbon dioxide technology. J Biomed Mater Res Appl Biomater. 2007;81(1): 185-93.

51. Tai H, Mather ML, Howard D, Wang W, White LJ, Crowe JA, et al. Control of pore size and structure of tissue engineering scaffolds produced by supercritical fluid processing. Eur Cells and Mater. 2007;14:64-76.

52. Park JW, Im SS. Morphological changes during heating in poly(L-lactic acid)/poly(butylene succinate) blend systems as studied by synchrotron X-ray scattering. J Polym Sci, Part B: Polym Phys. 2002;40(17):1931-9.

53. Di Lorenzo ML. The crystallization and melting processes of poly(L-lactic acid). Macromol Symp. 2006;234:176-83.

54. Pan P, Kai W, Zhu B, Dong T, Inoue Y. Polymorphous crystallization and multiple melting behavior of poly(L-lactide): molecular weight dependence. Macromolecules. 2007;40(19):6898-905.

55. Mihai M, Huneault MA, Favis BD, Li H. Extrusion foaming of semi-crystalline PLA and PLA/thermoplastic starch blends. Macromol Biosci. 2007;7(7):907-20.

56. Yu L, Liu H, Dean K, Chen L. Cold crystallization and postmelting crystallization of PLA plasticized by compressed carbon dioxide. J Polym Sci, Part B: Polym Phys. 2008;46(23):2630-6.

57. Kokturk G, Piskin E, Serhatkulu TF, Cakmak M. Evolution of phase behavior and orientation in uniaxially deformed polylactic acid films. Polym Eng Sci. 2002;42(8):1619-28.
58. Delabarde C, Plummer CJG, Bourban PE, Månson JAE. Accelerated ageing and degradation in poly-L-lactide/hydroxyapatite nanocomposites. Polym Degrad Stab. 2011;96:595-607.

59. Zheng G, Yang W, Liu C, Yang M, Chen J, Li Q, et al. Transcrystallinity in a polycarbonate $(\mathrm{PC}) /$ polyethylene $(\mathrm{PE})$ blend prepared by gas-assisted injection molding: a new understanding of its formation mechanism. J Macromol Sci Part B Phys. 2008;47(5):829-36.

60. Gibson LJ. Biomechanics of cellular solids. J Biomech. 2005;38(3):377-99.

61. Maiti SK, Gibson LJ, Ashby MF. Deformation and energy absorption diagrams for cellular solids. Acta Metall. 1984; 32(11):1963-75.

62. Gibson LJ, Ashby MF, editors. Cellular Solids Structure and Properties. Oxford: Pergamon Press; 1988.

63. Reitz DW, Schuetz MA, Glicksman LR. Basic study of aging of foam insulation. J Cell Plast. 1984;20(2):104-13.

64. Okamoto M, Nam PH, Maiti P, Kotaka T, Nakayama T, Takada M, et al. Biaxial flow-induced alignment of silicate layers in polypropylene/clay nanocomposite foam. Nano Lett. 2001;1(9):503-5.

65. Cao X, James Lee L, Widya T, Macosko C. Polyurethane/clay nanocomposites foams: processing, structure and properties. Polymer. 2005;46(3):775-83.

66. Giesen EBW, Ding M, Dalstra M, Van Eijden TMGJ. Mechanical properties of cancellous bone in the human mandibular condyle are anisotropic. J Biomech. 2001;34(6):799-803.

67. Zioupos P, Currey JD. Changes in the stiffness, strength, and toughness of human cortical bone with age. Bone. 1998;22(1): $57-66$.

68. WagonerJohnson AJ, Herschler BA. A review of the mechanical behavior of $\mathrm{CaP}$ and $\mathrm{CaP} /$ polymer composites for applications in bone replacement and repair. Acta Biomater. 2011;7(1):16-30.

69. Terrier A, Sedighi-Gilani M, Ghias AR, Aschwanden L, Pioletti DP. Biomechanical evaluation of porous biodegradable scaffolds for revision knee arthroplasty. Comput Methods Biomech Biomed Eng. 2009;12(3):333-9.

70. Renouf-Glauser AC, Rose J, Farrar D, Cameron RE. A degradation study of PLLA containing lauric acid. Biomaterials. 2005;26(15):2415-22.

71. Weir NA, Buchanan FJ, Orr JF, Dickson GR. Degradation of polyL-lactide. Part 1: in vitro and in vivo physiological temperature degradation. Proc Inst Mech Eng [H]. 2004;218(5):307-19.

72. Iannace S, Maffezzoli A, Leo G, Nicolais L. Influence of crystal and amorphous phase morphology on hydrolytic degradation of PLLA subjected to different processing conditions. Polymer. 2001;42(8):3799-807. 